\title{
Questions about Answers: Probing Teachers' Awareness and Planned Remediation of Learners' Misconceptions about Electric Circuits
}

\author{
Estelle Gaigher* \\ University of Pretoria, South Africa \\ *Email: estelle.gaigher@up.ac.za
}

This article reports an exploratory multi-case study on how science teachers understand and envisage addressing learners' misconceptions about electric circuits. Four teachers from schools in and around a large South African city participated in the study. An open-ended questionnaire was designed in a novel way, questioning teachers about wrong answers they expected from their learners in test items suitable for Grade 9. Semi-structured interviews supported the questionnaire results, providing insight into the teachers' understanding of learners' misconceptions, and their ideas about how learners' misconceptions should be addressed. Two of the teachers showed insight into learners' conceptual difficulties, reflecting on learners' thinking. Another teacher indicated some typical wrong answers but seldom understood the misconceptions leading to these mistakes, while the remaining teacher did not expect typical wrong answers corresponding to well-known misconceptions. All the teachers indicated that they would address learners' mistakes mostly by practical work or demonstrations, but only two of the teachers also referred to the importance of developing conceptual understanding. Results suggest that these teachers' understanding of learners' misconceptions relates to their own subject matter knowledge. Furthermore, the study showed that the technique of questioning teachers about anticipated learners' answers is a promising way of probing teachers' understanding of learners' misconceptions and the strategies they envisage using to address these misconceptions. It is recommended that learners' misconceptions be addressed explicitly in teacher preparation and professional development programmes as an avenue to develop teachers' pedagogical content knowledge (PCK).

Keywords: misconceptions; electric circuits; science teachers; conceptual understanding

\section{Introduction}

Students' misconceptions about electricity have been researched extensively since the early 1980 s (e.g. Cohen, Eylon, \& Ganiel, 1983; Shipstone, 1984). Alternative ideas develop from a young age resulting from children's practical experience with using electricity at home. By the time they reach high school, many learners have well-established misconceptions that are resistant to change despite teaching (Chambers \& Andre, 1997). Constructivists argue that learners' ideas should be a point of departure in teaching (Hammer, 1996; Smith, di Sessa, \& Roschell, 1993). It is therefore important that teachers are aware of learners' misconceptions in order to be able to design appropriate instruction (Morrison \& Lederman, 2003). If not addressed, learners' misconceptions may interfere with the development of appropriate scientific views.

Most studies on misconceptions deal with identifying or correcting learners' misconceptions while few focus on the teacher's role (e.g. Gunstone, Mulhall, \& McKittrick, 2009; Morrison \& Lederman, 2003). 
The current study contributes to closing this gap in the research literature and may ultimately contribute to improved teacher education. The article is partly based on an earlier conference presentation (van der Merwe \& Gaigher, 2011). In mathematics education, Moru and Qhobela (2013) similarly investigated mathematics teachers' awareness of learners' misconceptions regarding the concept of sets as a focus for teachers' pedagogical content knowledge (PCK) (Shulman, 1987).

The following research questions are addressed:

1. How do teachers understand learners' misconceptions about electric circuits?

2. How do teachers envisage addressing learners' misconceptions about electric circuits?

\section{Literature Review}

Electricity is regarded by learners and teachers as a difficult but important topic in school science syllabi (Gunstone et al., 2009). It is therefore not surprising to find a vast body of literature on alternative conceptions about electricity, in particular about simple direct current (DC) circuits. It has been shown that many misconceptions occur across cultural and language borders (Küç|üközer \& Kocakülah, 2007; Shipstone et al., 1988) and are held by children, students and university lecturers (Stocklmayers \& Treagust, 1996).

From the early literature, various misconceptions have been described. Sometimes the distinctions between 'different' misconceptions are unclear. Sencar and Eryilmaz (2004) compiled and discussed a list of common misconceptions from the literature: the sink/unipolar model; clashing currents; weakening current/current consumption/attenuation; shared current; empirical rule model; local and sequential reasoning; the short circuit preconception; the constant current source model; and the parallel circuit misconception. Engelhardt and Beichner (2004) included superposition reasoning as an additional misconception.

Some misconceptions are more common and persistent than others. According to Dupin and Joshua (1987), the weakening current and constant current source models are most persistent. Shipstone (1984) found that misconceptions for the most basic circuits generally decrease with increasing student age, while the use of the scientific model increases, from about $7 \%$ at age 12 to about $60 \%$ at age 17. Nevertheless, the weakening current model showed most resistance to change, with about $30 \%$ of 17 -year-olds still using it. Dupin and Joshua (1987) attributed the persistence of some models to the effects of teaching. For example, when emphasizing that current stays the same in a (particular) series circuit, teachers may unintentionally promote the development of the constant current source model.

Misconceptions about electricity have also been explored in South Africa. In an early study, Stanton (1990) found that learners' misconceptions about DC circuits were quite resilient despite teaching. A study of teachers showed their poor understanding of the model of conventional current (Smit \& Nel, 1993). Nkopane, Kriek, Basson, and Lemmer (2011) concluded that additional factors, including teachers' poor understanding of learners' pre-existing knowledge, contributed to South African learners' misconceptions. Recently, Mackay and Hobden (2012) reported that learners' circuit and wiring diagrams are useful to gain insight into their misconceptions regarding basic circuit electricity.

Morrison and Lederman (2003) argued that teachers need adequate understanding of preconceptions in order to support their learners. During an in-depth study using four experienced teachers, they found that teachers not only had poor understanding of preconceptions, but also did not regard the identification of preconceptions as useful. Gunstone et al. (2009) found that some experienced senior high school teachers and some textbook authors displayed poor conceptual understanding about DC electricity. Ironically, some of those teachers regarded electricity as easy to teach but hard to learn for students. Apparently, they had not previously reflected on the nature of some concepts, particularly voltage. The researchers argued that teachers' poor conceptual understanding may be indicative of poor teaching quality in undergraduate university physics courses. Pardhan and Bano (2001) proposed five sources of alternative conceptions among Pakistani teachers: the way teachers were taught; lack of hands-on and minds-on experience; mistakes in textbooks; daily life experiences; and everyday use of terminology. The authors expressed concern about 
embarrassing the teachers in the course of the study. The current study is designed to avoid embarrassing teachers by inquiring about learners' wrong answers.

\section{Conceptual Framework}

The study is founded on the well-known theoretical construct of pedagogical content knowledge (PCK) introduced by Shulman (1986) to represent the knowledge applied by teachers when transforming their own subject knowledge to make it comprehensible to learners. The construct was spawned by Shulman's concern over the absence of subject matter in research on teaching, which he regarded as a 'missing paradigm' (1986, p. 6). Shulman originally proposed three categories of content knowledge for teachers, namely subject matter content knowledge, PCK and curricular knowledge, but later expanded the list to seven categories, adding general pedagogical knowledge, knowledge of learners, knowledge of contexts and knowledge of educational goals (Shulman, 1987).

The construct of PCK has been researched extensively to characterize and measure it, and to introduce it in teacher education programmes (e.g. Lee \& Luft, 2008; Loughran, Mulhall, \& Berry, 2004). Several authors have attempted to describe the 'true nature' of PCK by suggesting taxonomies and components of PCK and teacher knowledge, rearranging and adding to Shulman's seven knowledge types (for an overview see Kind, 2009). For example, some researchers argue that generic aspects of teacher knowledge, such as general pedagogy and context, should be included as aspects of PCK (e. g. Veal \& MaKinster, 1999), while Hill, Ball, and Schilling (2008) regard knowledge of content and students, curricular knowledge and knowledge of content and teaching and as three aspects constituting PCK.

In the process of teasing out the nature of the construct, Shulman's focus on content is often overlooked (Hashweh, 2005; Hill et al., 2008). Mavhunga and Rollnick (2013) recently introduced a new term, 'topic-specific PCK', following earlier authors (Loughran et al., 2004; Veal \& MaKinster, 1999) who pointed out that Shulman's original conception of PCK was indeed topic specific. This term may become useful as it emphasizes Shulman's original concern about the absence of subject matter in research on pedagogy.

Shulman's original notion of PCK included representational knowledge as well as knowledge of learning difficulties (1986, pp. 9-10):

[PCK includes] knowledge of the most useful forms of representation of those ideas, the most powerful analogies, illustrations, examples, explanations and demonstrations ... [it] also includes an understanding of what makes learning of a specific topic easy or difficult: the conceptions and preconception that learners of different ages and backgrounds bring with them to the learning of those most frequently taught topics and lessons. If those preconceptions are misconceptions, which they so often are, teachers need knowledge of the strategies most likely to be fruitful in reorganizing the understanding of learners, because those learners are unlikely to appear before them as blank slate.

The aspects of representational knowledge and knowledge of learning difficulties make Shulman's description of PCK well suited to frame the current study. Teachers' understanding of learners' misconceptions and ways of addressing these are respectively interpreted as manifestations of knowledge of learner difficulties and representational knowledge, specifically in the topic of electricity.

\section{Method}

Participating teachers were purposively and conveniently selected to represent school contexts with learners from different socio-economic backgrounds in a South African city and for their willingness to participate. Participating teachers volunteered and were required to have more than four years of teaching experience to ensure exposure to learners' difficulties with the topic of electricity.

An open-ended questionnaire and a semi-structured interview were used to collect in-depth information on how participants understand and envisage addressing learners' misconceptions. The instruments were designed by the researcher and content validated by two science education specialists. 
Data were collected by two post-graduate students who completed individual projects under the supervision of the researcher.

The questionnaire, given in Appendix 1, focused on two well-known misconceptions. Specifically, the current attenuation and constant current models were targeted, as literature (Dupin \& Joshua, 1987) indicates these as being most resistant to change. Two multiple choice items, suitable for Grade 9 learners, were used in this study. The distracters represented misconceptions, a method proposed by Redish and Steinberg (1999) to investigate learners' misconceptions. The items were adapted from questions in the DIRECT test (Engelhardt \& Beichner, 2004). These two items and the correct options were given to the teachers, who were questioned about wrong answers they expected from learners. Teachers had to indicate which wrong answers they expected from learners, why they expected learners to choose those particular options and how they would address the mistakes. In this way, the questionnaire did not attempt to test teachers' subject knowledge. Instead, the questionnaire probes two aspects of Shulman's (1986) notion of PCK, i.e. teachers' knowledge of learner difficulties and their knowledge of representational strategies.

The data from the semi-structured interview, given in Appendix 2, provided insight into teachers' views about learners' difficulties as well as teaching electricity from a general perspective, without referring to specific circuits. This intersects with the questionnaire focus of understanding and resolving specific misconceptions, thereby providing an additional data source to enhance the trustworthiness of the study.

The questionnaire responses and transcriptions of interviews were analysed by means of content analysis (Denzin \& Lincoln, 2005; Neuendorf, 2002). In order to answer the first research question the data sets were scrutinized for the categories of misconceptions (Sencar \& Eryilmaz, 2004) that teachers expected their learners to exhibit. For the second research question the data sets were scrutinized, identifying key ideas and looking for similarities and differences in teachers' responses.

\section{Results}

Pseudonyms are used to refer to the teachers in this study to ensure anonymity. Richard had a threeyear science degree as well as a teaching diploma, Moses had a four-year science education degree, Pete had a two-year teaching diploma and Willy also had a two-year teaching diploma as well as a teaching certificate. Richard taught at an elite private school with excellent laboratory facilities and Moses taught at an upper middle class suburban school with a standard science laboratory. Pete taught at an inner city school that had some equipment for learners but no laboratory and Willy taught at a school in a poor township area without a laboratory but with some equipment, which he used for teacher demonstrations. All the teachers were male and all majored in physics, although these were not selection criteria. However, it is expected that there would be differences in the depth of their subject matter knowledge on the topic of electricity, related to the different types of qualifications.

\section{Results from the Questionnaire}

Weakening current/attenuation model

Question 1 probed teachers' understanding of the weakening current/attenuation model, and their ways of addressing this alternative idea. The correct answer is $A$; both $B$ and $E$ represent current attenuation for conventional current while $C$ and $D$ represent current attenuation for electron current. The teachers' responses are summarized in Table 1.

In this question all the teachers show awareness of the idea of the weakening current as all expected their learners to choose B as one of the two possibilities. This indicates that all the teachers know the typical mistake, but this is not sufficient evidence to conclude that they actually understand the current attenuation misconception. In fact, when inspecting their reasons for this expected mistake, only Moses gives a clear explanation that corresponds to the misconception. Richard's explanation that $A_{1}$ is 'closer to the cell' may suggest an awareness of either the current attenuation or the empirical rule model. (The latter is less well known; it is a belief that the current in a particular resistor is influenced by the length of the conductor between the cell and the resistor.) Pete's explanation involves 
Table 1: Summary of teachers' responses given to question 1

\begin{tabular}{|c|c|c|c|c|c|}
\hline Teacher & $\begin{array}{l}\text { First } \\
\text { choice }\end{array}$ & $\begin{array}{l}\text { Why would your } \\
\text { learners choose } \\
\text { this option? }\end{array}$ & $\begin{array}{l}\text { Second } \\
\text { choice }\end{array}$ & $\begin{array}{l}\text { Why would your learners } \\
\text { choose this option? }\end{array}$ & $\begin{array}{l}\text { How would you teach } \\
\text { learners to understand this } \\
\text { circuit? }\end{array}$ \\
\hline Richard & $B$ & $\begin{array}{l}A_{1} \text { is closer to the } \\
\text { cell. }\end{array}$ & $A$ & $\begin{array}{l}\text { They understand that the } \\
\text { current in a series } \\
\text { circuit is the same } \\
\text { everywhere. }\end{array}$ & $\begin{array}{l}\text { Using circuit boards and } \\
\text { voltmeters and ammeters, } \\
\text { practical experience is } \\
\text { what is needed. }\end{array}$ \\
\hline Moses & B & $\begin{array}{l}\text { Because they think } \\
\text { current } \\
\text { decreases when } \\
\text { it has passed } \\
\text { through the } \\
\text { resistor. }\end{array}$ & A & $\begin{array}{l}\text { Some of them know that } \\
\text { current in series is } \\
\text { constant. }\end{array}$ & $\begin{array}{l}\text { I would explain circuits by } \\
\text { starting with potential } \\
\text { difference. They must } \\
\text { understand that current } \\
\text { flows because of potential } \\
\text { differences at different } \\
\text { places in the circuit. }\end{array}$ \\
\hline Pete & $\begin{array}{l}\text { 'A }{ }_{2}^{\prime} \\
\text { No } \\
\text { choice }\end{array}$ & $\begin{array}{l}\text { Because they think } \\
\text { electricity is only } \\
\text { a flow of } \\
\text { electrons in one } \\
\text { direction. }\end{array}$ & B & $\begin{array}{l}\text { Because they feel that as } \\
\text { the ammeter marked } \\
\text { A1, it is the one that } \\
\text { offers more resistance } \\
\text { and hence must } \\
\text { consume more } \\
\text { current. }\end{array}$ & $\begin{array}{l}\text { I draw circuit diagrams firstly } \\
\text { illustrating series and } \\
\text { parallel connections. } \\
\text { Then I assemble all the } \\
\text { apparatus required in } \\
\text { different types of } \\
\text { connections. Furthermore } \\
\text { explanation on } \\
\text { differences. }\end{array}$ \\
\hline Willy & $\begin{array}{l}\text { B } \\
\text { and } \\
C\end{array}$ & $\begin{array}{l}\text { Because on } B \text {, } \\
A_{1}>A_{2} \text { and on } C, \\
A_{2}>A_{1} .\end{array}$ & $\mathrm{D}$ and $\mathrm{E}$ & $\begin{array}{l}\text { They may think from } A_{1} \text { to } \\
\text { the bulb is zero and } \\
\text { from the bulb to } A_{2} \text { is } \\
\text { also zero due to the } \\
\text { distance of the } \\
\text { conductors. }\end{array}$ & $\begin{array}{l}\text { Do the connection practically } \\
\text { and allow them to connect } \\
\text { themselves by giving the } \\
\text { simple instructions on } \\
\text { how to connect the } \\
\text { components. }\end{array}$ \\
\hline
\end{tabular}

an incorrect view about ammeters offering resistance, which does not reflect understanding of the weakening current misconception. Willy regards all the wrong answers as possible choices by his learners. His explanation is just a repetition of the given information. Although this does not exclude understanding, it indicates a poor attempt at explaining. With his second choice, he refers to the 'distance of the conductor' which may be an indication of some understanding of the empirical rule model.

Regarding the ways in which they would correct the mistake, all the teachers except Moses indicate that they would teach the concept of constant current in series circuits practically, either by demonstration or by involving learners in experimenting themselves. This may mean that they think it would be good enough for their learners to measure or 'see' that current is conserved, suggesting that they do not prioritize conceptual understanding. While Moses referred to understanding and Pete mentioned explaining, both were referring to teaching circuits in general, rather than current conservation in particular. Remarkably, not one of the four teachers suggested pointing out that it is electrical energy, not current, that is 'used', while the current is unchanged. Also, not one of them referred to mental models or to analogies to teach the concept.

\section{Constant current source}

Question 2 probed the teachers' understanding of the constant current source and the parallel circuit misconceptions represented by options $E$ and $C$ respectively. The data are presented in Table 2.

Three of the teachers choose option $E$ as one of their two choices, indicating knowledge of the typical mistake associated with the constant current misconception. Moses gives a very clear explanation. Pete indicates that learners would think the current that was previously flowing in $Q$ is still available, 
Table 2: Summary of teachers' responses to question 2

\begin{tabular}{|c|c|c|c|c|c|}
\hline Teacher & $\begin{array}{l}\text { First } \\
\text { choice }\end{array}$ & $\begin{array}{l}\text { Why would your } \\
\text { learners choose this } \\
\text { option? }\end{array}$ & $\begin{array}{l}\text { Second } \\
\text { choice }\end{array}$ & $\begin{array}{l}\text { Why would your learners } \\
\text { choose this option? }\end{array}$ & $\begin{array}{l}\text { How would you teach } \\
\text { learners to understand this } \\
\text { circuit? }\end{array}$ \\
\hline Richard & $C$ & $\begin{array}{c}\text { Because there are less } \\
\text { bubs in the circuit. }\end{array}$ & $E$ & $\begin{array}{l}A_{1} \text { is already in series and } \\
\text { will not be affected by } \\
\text { the removal of } Q \text {. }\end{array}$ & $\begin{array}{l}\text { Do the practical work using } \\
\text { circuit boards, } \\
\text { voltmeters and } \\
\text { ammeters. }\end{array}$ \\
\hline Moses & $E$ & $\begin{array}{l}\text { They expect that the } \\
\text { current in the circuit } \\
\text { stays the same, now } \\
\text { all the current } \\
\text { passes through } \mathrm{A}_{2} \text {. }\end{array}$ & C & $\begin{array}{l}\text { Because a resistor is } \\
\text { removed, they think the } \\
\text { total resistance } \\
\text { decreases and for this } \\
\text { reason the current will } \\
\text { increase. }\end{array}$ & $\begin{array}{l}\text { The same as the previous } \\
\text { experiment. }\end{array}$ \\
\hline Pete & C & $\begin{array}{l}\text { Because they think the } \\
\text { current will increase } \\
\text { as resistance is } \\
\text { reduced. }\end{array}$ & E & $\begin{array}{l}\text { Because they think the } \\
\text { first ammeter in the } \\
\text { connection is gaining } \\
\text { more current. }\end{array}$ & $\begin{array}{l}\text { I would teach them the } \\
\text { types of circuits and } \\
\text { practically demonstrate } \\
\text { using ammeters and } \\
\text { resistors connected in } \\
\text { parallel and series. }\end{array}$ \\
\hline Willy & B & $\begin{array}{l}\text { Because } A_{2} \text { is near to } \\
\text { the bulb. }\end{array}$ & D & $\begin{array}{l}\text { Because } A_{1} \text { is not near } \\
\text { the bulb the electricity } \\
\text { won't flow much at } A_{1} .\end{array}$ & $\begin{array}{l}\text { Give the learners the } \\
\text { values of the ammeters } \\
\text { so that they can do } \\
\text { correct calculations. }\end{array}$ \\
\hline
\end{tabular}

which represents the constant current source misconception. Richard's explanation does not clearly reflect the idea of a constant current source. However, his explanation ' $\mathrm{A}_{1}$ is already in series' may reflect the idea that current is the same in series, which has been associated with the constant current misconception (Dupin \& Joshua, 1987). On the other hand, it may also be an indication of local/sequential reasoning. Option $\mathrm{C}$, representing the parallel circuit misconception, was also chosen by the same three teachers. Their explanations indicate that they know some learners think that removing a resistor from a parallel connection decreases resistance as for series connections. Willy's choices do not show knowledge or understanding of either the constant current or the parallel circuit misconception.

When asked how they would teach this circuit, three of the teachers-Richard, Pete and Willy-claim that they would do it practically, without referring to conceptual understanding. Moses would use the same method as for the previous question, starting with potential difference, which suggests that he places emphasis on conceptual understanding, but once again he does not focus on understanding the question at hand. Also, he does not give an indication that practical work may be used. Willy also indicates that he would use calculations, suggesting that he values an algebraic approach. Not one of the teachers suggests pointing out that the cell is a source of constant potential difference, not constant current. Also, they do not suggest the use of mental models or analogies.

\section{Interviews}

The interview data not only supported answers given in the questionnaire, but also provided insight into teachers' own understanding about how electricity should be taught. These understandings are an indication of what Shulman (1986) described as representational knowledge, an aspect of teachers' PCK.

\section{Richard}

During the interview, Richard revealed that he regards practical work as very important. He starts the topic of electricity by giving learners circuit boards to try and connect a circuit, elaborating as follows: 
Interviewer: How do you usually start the topic of electricity?

Richard: $\quad$... just see what they do, you know, the basic idea ... the things need to be connected, a switch needs to be closed uhm ... those type of things ... the general things that children know even if they haven't necessarily been taught them.

He thinks that calculations become more important when learners are more advanced, indicating that he regards concepts as fundamental:

Interviewer: Do you think that mathematics is an important aspect when it comes to teaching electricity?

Richard: $\quad .$. I don't think initially it is important ... initially the concepts are not really mathematical, uhm ... you can teach electricity without a mathematical background uhm ... but later on as it becomes more complicated you would have more maths involved.

When asked about persisting incorrect ideas among his learners, he spontaneously describes an idea that may represent either the weakening current model or the empirical rule model.

Interviewer: Do you know of any incorrect ideas that persist despite teaching?

Richard: $\quad$ They ... a lot of them ... and even in matric still have the idea that a light bulb closer to the battery has more energy than light bulbs further away in a series circuit. They don't understand that the current in a series circuit is the same everywhere. They perceive position in a circuit as an indication of how strong the current is rather than whether it is in series or in parallel.

Interviewer: What can you do to replace these ideas with correct ones?

Richard: Let them take actual readings with a voltmeter and ammeter, uhm, ... let them test the different positions in the circuit. It has to be done practically ... I mean if you don't physically do it and see it uhm ... you will never understand it.

These answers support his responses in the questionnaire, ' $A_{1}$ is closer to the cell', and '... practical experience is what is needed'. Furthermore, the emphasis on practical work was also mentioned early in the interview. Therefore, Richard's interview and questionnaire data are in agreement, supporting the trustworthiness of the data.

\section{Moses}

Moses emphasizes the concept of energy when teaching electricity, explaining that 'they have to form the idea that we are talking about the transfer of energy', and 'the operation of a circuit is based on the creation of a potential difference'. He uses visual aids in the form of different colours for conductors on the two sides of the battery, and explains that the different colours connected to the resistor indicate a potential drop across it. Furthermore, he incorporates cause and effect by pointing out that learners should understand that potential difference causes current, not the other way round. Apart from his 'colour model' he also uses the water pipe analogy to explain that current is constant in a series circuit.

When asked about learners' persisting wrong ideas, he once again refers to potential difference:

Interviewer: Do you know about any wrong ideas about electricity that remain after you explained?

Moses: $\quad$ You find that sometimes children still do not understand correctly etc., they still think that two potential differences in parallel together has to give the total potential difference, that type of thing.

Interviewer: What can you do to help the learners if they keep getting it wrong?

Moses: I think, mmmm ... again they should experiment as much as possible.

Although Moses did not mention practical work in the questionnaire, in the interview he indicated that learners need to explore on their own. The data collected from Moses can be regarded as trustworthy, as he repeatedly refers to the concepts of energy and potential difference in the questionnaire as well as the interview. Also, in the questionnaire (question 1) he mentions that learners need to understand potential difference as the cause of current, indicating that he values conceptual understanding. 


\section{Pete}

During the interview, Pete indicates that he explains the theory, drawing circuits on the blackboard and demonstrating using a circuit board.

Interviewer: How do you usually start the topic of electricity?

Pete: $\quad$ OK what I usually do, is uh, I start by teaching them about voltage. I bring the concepts of voltage current and resistance, then from there I define the terms voltage, current and resistance. Then from there I move to inform my learners that uh, every circuit is different from the other circuits. We basically got two types of circuits in our everyday life we use. Then the first one is series, the other one is parallel. Then from there on I move to illustrate on the blackboard ...

Despite his focus on theory, he gives a hesitant, incorrect explanation of the meaning of voltage:

Interviewer: How do you explain the difference between current and voltage?

Pete: $\quad$... basically they have to know current is the flow of uh, uh, uh, electrons. Right from then from mathematically we have to know that uh, uh, voltage and current, I mean the, the, ... the voltage is actually amount of charge in a, source like a battery. Now current is the flow of charge in a circuit, ya.

According to Pete, learners often have difficulty calculating resistance in parallel circuits. While not mentioning the conceptual difficulty in understanding the effect of adding resistances in parallel circuits, he gives a lengthy explanation of the algebra involved, referring to 'another formula' that he uses:

Interviewer: Do you know of any incorrect ideas that your learners may have that persist after studying the topic?

Pete: When it comes to calculation of resistance now in parallel and series connection. In series connection they don't have a problem ... But now I realized that there is another formula which can be easily grasped by learners especially when you are looking at resistances in parallel. The one that says that 1 divided by $R_{\text {total }}$ is equal to 1 over $R_{1}$ plus 1 over $R_{2}$, uh, going on like that. Now l've come up with another method... Maybe I can illustrate you some ... [continues to work on a numerical example].

During the interview and in the questionnaire, Pete often referred to differences between series and parallel circuits, which added trustworthiness to the data. His incorrect distinction between current and voltage suggests that he has inadequate understanding of fundamental concepts. This might explain why he focuses on theory and algebra rather than on conceptual understanding. He emphasizes physical and algebraic differences between series and parallel circuits but overlooks conceptual differences.

\section{Willy}

Willy relates electricity to learners' everyday experiences at home:

Interviewer: How do you usually start the topic of electricity?

Willy: $\quad$ By asking learners what they understand by the term electricity. Where can electricity be found and how it is used.... I will ask them simple questions. How do they make tea at home and how do they use electricity for other things?

Willy's answers in the interview suggest that he lacks fundamental understanding of electric circuits. He focuses on physical connections of circuits and gives simplistic explanations of abstract concepts:

Interviewer: How do you explain series and parallel circuits?

Willy: I can explain series by telling them that ammeter is connected in series in a circuit. Parallel I can show them voltage is connected, is connected across a circuit so I have to draw the diagram for both series and parallel. I can use the ammeter and voltage to show them.

Interviewer: How do you explain the difference between current and voltage? 
Willy: $\quad$ Current is all about the flowing of charge. Voltage is about the two terminals of the battery in a circuit. I can also use Ohm's law.

Regarding learners' persisting incorrect ideas, he mentioned lightning. However, to help learners understand, he did not offer any conceptual explanation of lightning as an electric phenomenon. Instead he suggested showing calculations and providing conductors and insulators:

$\begin{array}{ll}\text { Interviewer: } & \text { Do you know of any incorrect ideas that your learners may have that persist after studying } \\ \text { the topic? } & \text { Yes, for example lightning may come in form of shocking people in form of electricity but } \\ \text { Willy: } & \begin{array}{l}\text { learners will start asking questions about lightning and electricity, not knowing the } \\ \text { difference. }\end{array} \\ \text { Interviewer: } & \text { What do you do in order to help your learners replace these ideas with scientifically correct } \\ \text { ones? } & \begin{array}{l}\text { Showing them scientifically correct calculations. I can also provide them with components } \\ \text { Willy: }\end{array}\end{array}$

It is not clear if the reference to conductors and insulators was meant to address safety during thunderstorms, or whether it was simply mentioned as one of the typical classroom experiments. Unfortunately, the interviewer did not probe further. Nevertheless, Willy's data can be regarded as trustworthy because in both the interview and the questionnaire he revealed poor conceptual understanding of the topic of electricity, and his suggestions were to do calculations and demonstrations (without mentioning conceptual understanding) as a way of correcting learners' poor understanding. Willy's emphasis on calculations seems similar to the situation observed by Hobden (2004), who warned that learners may fail to develop an understanding that physics is an integrated set of concepts and principles.

\section{Discussion and Conclusion}

Agreement between interview responses and the questionnaire answers supports the trustworthiness of the results. This indicates that the 'questions about answers' approach introduced in this study is a promising way to access teachers' understanding of learners' misconceptions and their thoughts about how to address learners' mistakes. Therefore, the method may be useful to explore teachers' PCK.

In conclusion, results indicate that two of the teachers, Richard and Moses, show understanding of learners' misconceptions and that they value the development of learners' conceptual understanding in correcting misconceptions. This insight and planned intervention demonstrate relevant topic-specific PCK (Lee \& Luft, 2008). The first research question probed understanding of learners' misconceptions in electricity. Richard and Moses reflect on learners' thinking and their conceptual difficulties. On the other hand, Pete anticipates some typical wrong answers but seldom understands the misconceptions leading to these mistakes, while Willy does not expect the typical wrong answers corresponding to well-known misconceptions.

The second research question explores how teachers envisage addressing misconceptions. While all the teachers indicate that they would use practical work or demonstrations to address learners' mistakes, only Richard and Moses also refer to developing conceptual understanding. Pete and Willy do not indicate concern about conceptual understanding; instead they suggest that learners should learn to do correct calculations. This lack of insight into learners' misconceptions demonstrates inadequate topic-specific PCK. In fact, the data also reveal that these two teachers themselves have poor conceptual understanding about circuits, preventing them from understanding learners' misconceptions. They suggest addressing misconceptions through calculations and demonstrations, which indicates generic pedagogical knowledge, which has little value if the teacher lacks the topic-specific PCK.

Apart from the differences found between these four teachers' approaches to correcting mistakes, a remarkable similarity was detected: all four teachers focus on teaching correct answers in their own ways, without confronting the wrong answers, suggesting that they do not consider conceptual change as a possible approach. 
There are limitations to the current study. Clearly, conclusions should not be generalized as this was an exploratory multi-case study using a small sample. Language issues may have influenced data, as Richard was the only participant who could use his first language (English) in both the interview and questionnaire. The format of the questionnaire may be another limitation. It is possible that a teacher may be aware of a misconception but thinks his own learners would not make such a mistake. However, in this study, using interviews as a second source of data supports conclusions drawn from the questionnaire, thus enhancing trustworthiness.

It is recommended that professional development and initial teacher training should emphasize conceptual understanding of the scientific model of simple electric circuits, misconceptions about circuits as well as addressing these misconceptions. Furthermore, it is recommended that more research be conducted to explore correspondence between teachers' intentions (for instance, as emerging from this study) and classroom practice regarding the correction of misconceptions.

\section{References}

Chambers, S., \& Andre, T. (1997). Gender, prior knowledge, interest, and experience in electricity and conceptual change text manipulations in learning about direct current. Journal of Research in Science Teaching, 34, 107123.

Cohen, R., Eylon, B., \& Ganiel, U. (1983). Potential difference and current in simple electric circuits: A study of students' concepts. American Journal of Physics, 51, 407-412.

Denzin, N. K., \& Lincoln, Y. S. (Eds.). (2005). Handbook of qualitative research (2nd ed.). Thousand Oaks, CA: Sage.

Dupin, J. J., \& Joshua, S. (1987). Conceptions of French pupils concerning electric circuits: Structure and evolution. Journal of Research in Science Teaching, 24, 791-806.

Engelhardt, P., \& Beichner, R. J. (2004). Students' understanding of direct current resistive electrical circuits. American Journal of Physics, 72, 98-115.

Gunstone, R., Mulhall, P., \& McKittrick, B. (2009). Physics teachers' perceptions of the difficulty of teaching electricity. Research in Science Education, 39, 515-538.

Hammer, D. (1996). Misconceptions or p-prims: How many alternative perspectives of cognitive structure influence instructional perceptions and intentions? Journal of the Learning Sciences, 5, 97-127.

Hashweh, M. Z. (2005). Teacher pedagogical constructions: A reconfiguration of pedagogical content knowledge. Teachers and Teaching: Theory and Practice, 11, 273-292.

Hill, H. C., Ball, D. L., \& Schilling, S. G. (2008). Unpacking pedagogical content knowledge: Conceptualizing and measuring teachers' topic-specific knowledge of students. Journal of Research in Mathematics Education, 39 , $372-400$.

Hobden, P. (2004). Is this the kind of physics education that encourages students to study physics? Paper presented at the International Physics Education Conference, Durban, South Africa, 5-8 July.

Kind, V. (2009). Pedagogical content knowledge in science education: Perspectives and potential for progress. Studies in Science Education, 45, 169-204.

Küçüközer, H., \& Kocakülah, S. (2007). Secondary school students' misconceptions about simple electric circuits. Journal of Turkish Science Education, 4, 101-115.

Lee, E., \& Luft, J. A. (2008). Experienced secondary science teachers' representations of pedagogical content knowledge. International Journal of Science Education, 30, 1343-1363.

Loughran, J., Mulhall, P., \& Berry, A. (2004). In search of pedagogical content knowledge in science: Developing ways of articulating and documenting professional practice. Journal of Research in Science Teaching, 41, 370-391.

Mackay, J. \& Hobden, P. (2012). Using circuit and wiring diagrams to identify students' preconceived ideas about basic electric circuits. African Journal of Research in Mathematics, Science and Technology Education, 16, 131144.

Mavhunga, E., \& Rollnick, M. (2013). Improving PCK of chemical equilibrium in pre-service teachers. African Journal of Research in Mathematics, Science and Technology Education, 17, 113-125.

Morrison, J. A., \& Lederman, N. G. (2003). Science teachers' diagnosis and understanding of students' preconceptions. Science Education, 87, 849-867.

Moru, E. K., \& Qhobela, M. (2013). Secondary school teachers' pedagogical content knowledge of some common student errors and misconceptions in sets. African Journal of Research in Mathematics, Science and Technology Education, 17, 220-230. 
Neuendorf, K. A. (2002). The content analysis handbook. Thousand Oaks, CA: Sage.

Nkopane, L., Kriek, J., Basson, I., \& Lemmer, M. (2011). Alternative conceptions about simple electric circuits amongst high school FET band learners. In Proceedings of the International Conference of Science, Mathematics and Technology Education held at Kruger Park, October 2011 (pp. 339-353). 'Pretoria: Unisa Press'.

Pardhan, H., \& Bano, Y. (2001). Science teachers' alternate conceptions about direct currents. International Journal of Science Education, 23, 301-318.

Redish, E. F., \& Steinberg, R. N. (1999). Teaching physics: Figuring out what works. Physics Today, 52, 24-30.

Sencar, S., \& Eryilmaz, A. (2004). Factors mediating the effect of gender on ninth-grade Turkish students' misconceptions concerning electric circuits. Journal of Research in Science Teaching, 41, 603-616.

Shipstone, D. M. (1984). A study of children's understanding of electricity in simple DC circuits. European Journal of Science Education, 6, 185-198.

Shipstone, D. M., Rhöneck, C.V., Kärrqvist, C., Dupin, J., Joshua, S., \& Licht, P. (1988). A study of students' understanding of electricity in five European countries. International Journal of Science Education, 10, 303-316.

Shulman, L. S. (1986). Those who understand: Knowledge growth in teaching. Educational Researcher, 15(2), 4-14.

Shulman, L. S. (1987). Knowledge and teaching: Foundations of the new reform. Harvard Educational Review, 57, $1-21$.

Smit, J. J. A., \& Nel, S. J. (1993). Perceptions of models of electric current held by physical science teachers in South Africa. South African Journal of Science, 97, 202-212.

Smith, J. P., di Sessa, A. A., \& Roschell, J. (1993). Misconceptions reconceived: A constructivist analysis of knowledge in transition. Journal of the Learning Sciences, 3, 115-163.

Stanton, M. (1990). Students' alternative conceptions of the DC circuit. Spectrum, 28, 32-38.

Stocklmayers, M., \& Treagust, D. F. (1996). Images of electricity: How do novices and experts model electric current?. International Journal of Science Education, 18, 163-178.

Van der Merwe, O. R., \& Gaigher, E. (2011). Teachers' awareness of learners' misconceptions about simple circuits. In Proceedings of the International Conference of Science, Mathematics and Technology Education held at Kruger Park, October 2011 (pp. 181-190). Pretoria: Unisa Press.

Veal, W. R., \& MaKinster, J. G. (1999). Pedagogical content knowledge taxonomies. Electronic Journal of Science Education, 3. Available from http://ejse.southwestern.edu

\section{Appendix 1: Questionnaire for Science Teachers}

Question 1. Suppose your learners were given the following question in a test:

How do the readings on the ammeters $\mathrm{A}_{1}$ and $\mathrm{A}_{2}$ compare?
A $\quad \mathrm{A}_{1}=\mathrm{A}_{2}$
B $\quad \mathrm{A}_{1}>\mathrm{A}_{2}$
C $\quad \mathrm{A}_{1}<\mathrm{A}_{2}$
D $\quad \mathrm{A}_{1}=0$
E $\quad \mathrm{A}_{2}=0$

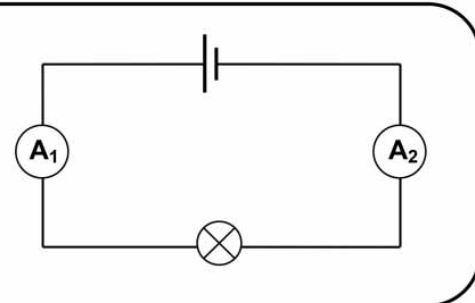

\section{The correct answer is A. Please answer the following questions:}

1.1 Which one of the incorrect answers B, C, D or E do you think your learners are most likely to choose?

1.2 Why do you think they are likely to choose this answer?

1.3 Which of the remaining options do you think some of your learners might choose?

1.4 Why do you think they might choose this answer?

1.5 How would you teach circuits to help your learners develop the correct understanding about this circuit? 


\section{Question 2. Suppose your learners were given the following question in a test:}

Suppose bulb Q is removed from the socket, how would the ammeter readings change?
A $\mathrm{A}_{1}$ decreases, $\mathrm{A}_{2}$ stays the same.
B $A_{1}$ decreases, $A_{2}$ increases.
C both increase.
D $A_{1}$ stays the same, $A_{2}$ decreases.
E $A_{1}$ stays the same, $A_{2}$ increases.

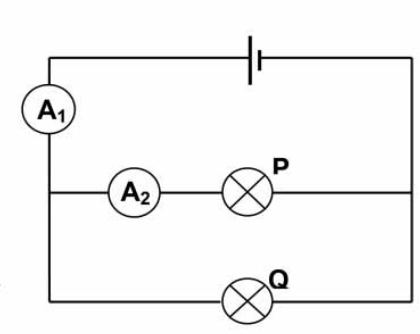

The correct answer is A. Please answer the following questions:

2.1 Which one of the incorrect answers B, C, D or E do you think your learners are most likely to choose?

2.2 Why do you think they are likely to choose this answer?

2.3 Which of the remaining options do you think some of your learners might choose?

2.4 Why do you think they might choose this answer?

2.5 How would you teach circuits to help your learners develop the correct understanding about this circuit?

\section{Appendix 2: Interview Schedule}

1. How do you usually start the topic of electricity?

2. How do you assess what the learners' prior knowledge is regarding electricity?

3. Do you think that mathematics is an important aspect when it comes to teaching electricity?

4. How do you explain series and parallel circuits?

5. How do you explain the difference between the terms 'current' and 'voltage'?

6. Do you use any models/analogies when explaining electricity? Please elaborate.

7. Do you know of any incorrect ideas your learners may have regarding electricity that tend to persist after studying the topic?

8. What do you do in order to help your learners replace these ideas with scientifically correct ones?

9. Can you think of any other ways in which to improve learners' understanding regarding electricity? 